\title{
Reflexões sobre o que é ser professor do ensino superior
}

Universidade Estadual do Rio Grande do Sul (UERGS). Unidade Universitária Porto Alegre.

Janaína Carneiro da Silva

Universidade Federal do Rio Grande do Sul (UFRGS). Programa de Pós-

Graduação em Políticas Públicas (doutoranda).

E-mail: janaina-carneiro@uergs.edu.com.br

\section{DOI: http://dx.doi.org/10.21674/2448-0479.41.1-2}

Vivemos em um mundo pleno de contradições. Por um lado, o rápido desenvolvimento das tecnologias dispararam um estilo de vida - life style - que até a pouco estava circunscrito aos roteiros de filmes futuristas. Por outro, ainda podemos nos considerar na idade da pedra se levarmos em conta a distância que separa, por exemplo, um país da África subsaariana em conseguir erradicar a pobreza extrema e a fome em comparação com nações territorialmente imensas como o Brasil que enfrentam desigualdades equivalentes dentro de seu próprio território nacional.

$\mathrm{Na}$ agenda internacional, inovação e desenvolvimento são as temáticas da época. Assim como o cenário proposto no Paris +10 onde a educação, a pesquisa e a inovação - com responsabilidade social - são a ordem da década para as instituições de ensino superior (NEZ, 2011). Mas para quem? E por quem? Sua proposta de ampliar o escopo da universidade para serviço do desenvolvimento e da inovação já é percebida ao passo que algumas Universidades, hoje chegam a parecer pequenas cidades que incorporam empresas, entidades de classes e órgãos comerciais de serviços configurando-se, por vezes em verdadeiros shopping centers. (PEREIRA, 2013).

Não que isto seja, por si só, de qualquer forma negativo. O progresso, por princípio é positivo. Entretanto, quando conjuntamente, temos políticas de demissões em massa de docentes, exclusão curricular de componentes de base para formação social do indivíduo e supervalorização das exatas e das técnicas já na formação básica, se faz evidente a necessidade de, ao menos, refletirmos sobre o tema.

Neste cenário, me pergunto para onde vai à educação universitária? Quais os caminhos que estará trilhando nos próximos anos? Sem poder deixar de pensar que existe aí um ator que, na maioria das vezes não tem ouvida sua voz na tomada de decisões sobre as políticas educacionais nacionais e internacionais, mas sendo quem efetivamente está no front de batalha: o professor universitário.

Teoricamente, este ator, tem o papel de implementar dentro da sala de aula as políticas de ensino determinadas por órgãos regulamentadores que determinam as diretrizes e bases educacionais de uma nação. Por assim dizer, formar a massa crítica da sociedade. Entretanto, esta formação passa por diversas etapas que, extrapolam por vezes, as capacidades de um corpo docente de executá-las. Seja por não estarem tecnicamente preparados, seja por não estarem politicamente engajados com tais diretrizes e bases. Mas o que seria formar a massa crítica da sociedade? Formar para o trabalho técnico especializado? Formar para a vida? Formar para o convívio social? Formar para terem suas próprias opiniões? Ou quem sabe tudo isto junto? 
O papel do professor, segundo Alves (2013), Sociólogo da UFRGS, é "fornecer instrumentos de pensamento aos alunos". Ou seja, ensinar a pensar por si próprio. Esta definição está muito próxima de uma política emancipatória onde o professor é o agente facilitador de um desenvolvimento pessoal pelo qual os jovens são conduzidos a passar e, por meio do qual, o produto esperado é um indivíduo mais maduro, autônomo e consciente de suas competências e habilidades podendo empregá-las no decorrer de sua vida como ativo pessoal, intransferível e inalienável.

Entretanto, as dificuldades andam sempre juntas com as benesses. Quando Dubet (1996) afirma que "A pedagogia é uma técnica da operacionalização da personalidade. Quando se pede a um professor para mudar o seu método, não se pede apenas que ele mude de técnica, pede-se para que ele próprio mude" coloca mais uma atribuição à já árdua tarefa de ensinar. Pois sim, ensinar é difícil. E ser professor universitário é estar disponível mental e emocionalmente para enfrentar estas dificuldades objetivando a formação de um aluno consciente, competente, habilidoso e humano no desempenho de sua vida acadêmica, profissional e adulta. Ser um bom professor, para mim, é conseguir atingir estes objetivos e sentir-se feliz com isto. Sentir-se capaz de mudar, não apenas o discurso, mas quantas vezes forem necessárias para entrar em sala de aula com algo relevante, desafiador e sair dela com a sensação de paz por, se não no todo, pelo menos em parte, ter acalmado angústia do saber de quem quer apreender.

Enfim, para ser um bom professor universitário é necessário ter autoconhecimento e maturidade para adequar-se com personalidade à atividade docente. Ou seja, saber o que the serve e o que não the serve em cada momento da atividade pedagógica. Algo muito mais complexo que qualquer filosofia de "com ou sem partido". Penso que sim, precisamos resgatar o propósito para, a partir deste, refletirmos as práticas. Enfim, uma breve reflexão sobre o que é ser Professor no Ensino Superior...

\section{REFERÊNCIAS:}

ALVES, C. F. O que é ser Professor? Palestra para disciplina de Metodologia do Ensino Superior. Porto Alegre: PUCRS, 2013.

NEZ, E. de. Processo de Bolonha (Espaço Europeu do Ensino Superior - EEES): Políticas Públicas para a Educação Superior Brasileira? ANPAE, 2011. Disponível em:< http://www.anpae.org.br/simposio2011/cdrom2011/PDFs/trabalhosCompletos/posters/0052.pdf> Acesso em: 18 jan. 2018.

PERALVA, A. T.; SPOSITO, M. P. Quando o sociólogo quer saber o que é ser professor - Entrevista com François Dubet. Espaço Aberto, n. 5, 1997.

PEREIRA, V. M. A hegemonia da prática e a globalização da educação superior. Porto Alegre: PUCRS, 2013. 